\title{
«Nos traen tan avasallados hasta quitarnos nuestro seńorío»: cabildos mayas, control local y representación legal en el Yucatán del siglo XVI
}

\author{
CAROLINE CUNILL \\ Université du Maine \\ cunillcaroline@gmail.com
}

\section{RESUMEN}

Al igual que en la peninsula ibérica, en la América colonial se superpusieron distintas jurisdicciones en el mismo espacio, de modo que el complejo entramado político del Nuevo Mundo estaba conformado, a nivel local, por los cabildos indigenas y españoles, las doctrinas y los corregimientos. Aunque los representantes de aquellas instituciones recibieron detalladas instrucciones en las que la Corona española definia y limitaba sus funciones y prerrogativas, fueron frecuentes las tensiones entre los gobernadores indigenas, los alcaldes ordinarios, los curas beneficiados y los corregidores. A partir de una serie de pleitos en los que estuvieron involucradas estas autoridades, el presente trabajo analiza tanto la naturaleza de los conflictos jurisdiccionales que tuvieron lugar en el Yucatán del siglo XVI como las modalidades de su resolución en los foros de justicia de la Monarquia hispana. Se presta especial atención a la jurisdicción de los cabildos mayas con el fin de esclarecer el alcance de la participación indigena en el sistema politico del Imperio hispánico. Consideramos que el control local, por un lado, y la representación legal, por otro, resultan fundamentales para comprender aquellos fenómenos.

Palabras clave: cabildos indígenas, jurisdicción, representación legal, mayas, Yucatán

*Agradezco a José Carlos de la Puente Luna por su atenta lectura y valiosas sugerencias, que contribuyeron a mejorar el presente trabajo.

HISTORIOA XL.2 (2016): 49-80 / ISSN 0252-8894

https://doi.org/10.18800/historica.201602.002 


\section{ABSTRACT}

In Spanish Colonial America, as well as in the Iberian Peninsula at the same time, different jurisdictions intertwined in the same space. By way of consequence, the complex political organization of the New World was composed, at the local level, by the Indian and Spanish Councils, the doctrines, and the provincial structures called corregimientos. Although the officials of those institutions received precise instructions, in which the Spanish Crown defined and limited their functions, tensions were common between the Indian governors, the clergymen, the Spanish Council's officeholders, and the Spanish provincial magistrates, or corregidores. The present article will analyze a series of lawsuits that occurred in sixteenth century Yucatan and in which those authorities were implicated, in order to highlight not only the nature of the jurisdictional conflicts, but also the modalities of their resolution at stake in the Spanish Empire's courts of justice. Special emphasis will be put on the jurisdiction of the Maya Councils with the objective of better understanding the scope of indigenous agency in Spanish Colonial America. We argue that the local control on the one hand, and the legal representation on the other, were key elements in these processes.

Keywords: Indian Councils, jurisdictions, legal representation, Mayas, Yucatan

Acidad política de los pueblos indígenas de América y brindó a las autoridades autóctonas jurisdicción sobre sus comunidades. ${ }^{1}$ No obstante, mediante el reconocimiento del señorío natural y la posibilidad de recurrir a los antiguos usos y costumbres autóctonos siempre que no contradijeran la policía cristiana, la Monarquía hispana solo otorgó una validez parcial a la organización sociopolítica prehispánica. ${ }^{2}$ De hecho, las autoridades reales, con el apoyo de los religiosos, se esforzaron por imponer la religión cristiana y las leyes de Castilla como criterios rectores de la vida política del Imperio hispánico. Por consiguiente, los pueblos de indios de América fueron sometidos a una profunda reorganización

1 Quijano 2012.

2 Encinas 1945, IV: 356; y Herzog 2013. 
tanto territorial, como institucional: fueron reducidos y la jurisdicción de las autoridades autóctonas fue ejercida a través de los cabildos indígenas, integrados por un gobernador, dos alcaldes y dos regidores. En Yucatán, las visitas de los oidores Tomás López Medel (1552) y Diego García de Palacio (1583), así como las instrucciones que ambos oficiales dejaron a los pueblos de indios, desempeñaron un papel determinante en la institucionalización de los cabildos indígenas en la provincia. ${ }^{3}$ Pese a ello, existieron fenómenos de hibridación entre las estructuras y conceptos políticos mayas y espańoles, perceptibles en los documentos notariales generados por los escribanos mayas. ${ }^{4}$ Así, en numerosos casos los gobernadores mayas también se identificaron como batab, recurriendo a las denominaciones y categorías prehispánicas.

No cabe duda de que los cabildos mayas gozaron de un amplio margen de autonomía en el gobierno de sus comunidades, favorecido por la relativa indiferencia de las autoridades españolas, más allá de los procesos de explotación de la mano de obra y de extracción de diversas mercancías. ${ }^{5}$ Según Sergio Quezada, en efecto, las funciones de los oficiales del cabildo maya abarcaron tareas tan diversas como mandar a construir y reparar caminos, asegurarse de que los indígenas cultivaran sus milpas, realizar censos de población, recoger y entregar el tributo, cuidar que los mayas asistieran a misa, y prevenir y castigar los pecados públicos y los delitos. ${ }^{6}$ No obstante, aún se puede profundizar en la comprensión del concepto de gobierno indígena en el Imperio hispánico. Para ello, sugerimos que es conveniente adoptar una visión más crítica con respecto a las nociones de autogobierno y autonomía indígenas, que conllevan la idea de un funcionamiento aislado y autocentrado de las comunidades indígenas y de un ámbito de poder de sus cabildos limitado al nivel local.

Enfocarse en el concepto de jurisdicción indígena, uno de los principales ejes de la organización política de la Monarquía hispana, permite renovar la reflexión sobre el gobierno indígena. Este enfoque permite,

3 Farriss 2012; y Quezada 2014.

4 Restall 1997; Quezada y Okoshi Harada 2001; y Hanks 2010.

5 Güémez Pineda 2005; Lentz 2012; y Thompson 1999.

6 Quezada 2014: 55-59. 
además, plantearla en los términos de la época. En las sociedades del Antiguo Régimen, la jurisdicción no se entendía en términos estrictamente territoriales (con fronteras claramente delimitadas), sino más bien en términos de competencias, de modo que tanto la multiplicidad de jurisdicciones como los conflictos derivados de ella eran constitutivos de la forma de gobernar. ${ }^{7}$ El sistema de justicia permitía mantener un equilibrio entre los distintos cuerpos que conformaban las monarquías «compuestas» del Antiguo Régimen; la figura del rey se concebía como la de un juez o árbitro supremo. ${ }^{8}$ El amparo real, que brindaba el monarca a sus vasallos más necesitados, suavizaba las diferencias pero no las borraba, dado que el orden jurídico se caracterizaba por la pluralidad.

Por lo tanto, al otorgar a los cabildos indígenas la jurisdicción sobre sus pueblos, la Corona española brindó a las autoridades autóctonas la oportunidad de desempeñar un destacado papel en los conflictos que surgieron en la sociedad colonial. Así, pues, no se puede entender la jurisdicción de los cabildos indígenas como estática y aislada, sino que conviene más bien preguntarse cómo esta se insertó en el complejo andamiaje político del Imperio hispánico y qué estrategias usaron los actores indígenas para mantener $y$, eventualmente, ensanchar sus competencias jurisdiccionales en este contexto. En el presente trabajo, mostraremos que la jurisdicción de los cabildos mayas de Yucatán fue materia de disputa con los curas beneficiados, los alcaldes ordinarios, los corregidores y, de manera más esporádica, con los jueces de comisión y los visitadores civiles y eclesiásticos. Asimismo, veremos que la necesidad de preservar su jurisdicción a nivel local empujó a los actores mayas a trascender el ámbito de sus propios pueblos y a tratar de ser representados en distintos foros de justicia de la Monarquía hispana con el fin de influir en los procesos de arbitraje y resolución de los conflictos. En otras palabras, consideramos que tres conceptos fueron claves en el funcionamiento

7 Grossi 1996; Prodi 2000; y Garriga 2006.

8 Se retoma aquí el título de la obra de Russell y Andrés-Gallego 1996. Véase, además, Elliott 1992. 
político de la provincia: los conflictos jurisdiccionales, el control local y la representación jurídica.

Para comprender cabalmente los conflictos y las alianzas que surgieron y se fraguaron en Yucatán, hay que tomar en cuenta la historia de la implantación de las autoridades que gozaron de jurisdicción en los pueblos de indios de la provincia en el siglo XVI. Nancy Farriss nos recuerda que, pese a los importantes cambios sociopolíticos introducidos por los espańoles a raíz de la conquista, los gobernantes mayas representaron el "centro fijo" del que no pudieron prescindir los colonizadores para administrar el territorio. ${ }^{9}$ Como es sabido, los franciscanos, por su lado, se instalaron en Yucatán hacia 1545, apenas terminada la conquista militar. ${ }^{10}$ Finalmente, la jurisdicción de los cabildos españoles para gobernar y administrar justicia se extendió a amplios territorios, debido a que no estaban claramente definidos los términos de las ciudades y villas y a que las comunidades indígenas carecían de representantes de la justicia real fuera de las autoridades mayas. ${ }^{11}$ De este modo, aunque la Corona se negó a conceder a los encomenderos jurisdicción sobre los indígenas, los cabildos espańoles se convirtieron en un «instrumento político» al servicio de la oligarquía local, puesto que los encomenderos monopolizaron los cargos capitulares. ${ }^{12}$ En otras palabras, la autoridad de que gozaban los encomenderos en los pueblos de indios estaba respaldada institucionalmente por los cabildos españoles. En vista de ello, no extraña que, en el Yucatán de principios del periodo colonial, la mayoría de los conflictos y de las alianzas involucraran a los gobernadores mayas, los religiosos, los encomenderos y los cabildantes españoles. En la década de 1570, la aparición en la provincia de un nuevo actor político, el corregidor, originó el surgimiento de nuevas confrontaciones y renovados pactos.

9 Farriss 2012: 303-326.

${ }^{10}$ González Cicero 1978.

${ }^{11}$ Bayle 1952: 101-104 y 159-160.

12 García Bernal 2000. 


\section{ALIANZAS, CONFLICTOS Y EJERCICIO DE LA JURISDICCIÓN INDÍGENA EN EL ÁMBITO LOCAL}

En la década de 1550, los franciscanos fueron los principales aliados de los mayas para contrarrestar el poder de los encomenderos. Gracias a la intervención de los religiosos ante la Corona espańola, por ejemplo, se tasó y reguló por primera vez el tributo indígena y el servicio personal en la provincia. ${ }^{13}$ Menos conocida es la serie de juicios inquisitoriales que los franciscanos presentaron ante el juez apostólico fray Francisco Navarro, guardián del monasterio de la Madre de Dios, ubicado en los extramuros de la ciudad de Mérida, en contra de varios vecinos y encomenderos. ${ }^{14}$ De especial interés resulta el proceso en el que Francisco Hernández fue acusado de impedir que sus encomendados asistiesen a la doctrina y que los niños mayas fuesen a la escuela del convento de Valladolid. ${ }^{15}$ No cabe duda de que lo que estaba en juego en aquellos conflictos era la jurisdicción sobre la población autóctona y, de paso, el control de la mano de obra que tanto los encomenderos como los religiosos necesitaban para desarrollar sus respectivas actividades, desde la construcción de iglesias y monasterios hasta la recaudación de tributos y otras mercancías. La petición de fray Bartolomé de Las Casas para que los indígenas, a quienes se aplicaría la condición jurídica de miserable, dependieran de la justicia eclesiástica, sugiere que incluir a la población autóctona en una jurisdicción determinada representaba uno de los principales retos

${ }^{13}$ García Bernal 1982.

${ }^{14}$ Proceso contra Francisco de la Vega por blasfemo, 1560. Archivo General de la Nación de México [en adelante AGN], Inquisición, vol. 16, exp. 5, ff. 253-268; Proceso contra Gregorio de Valdivia por blasfemo, 1560. AGN, Inquisición, vol. 16, exp. 10, ff. 754-773; Proceso contra Antonio Ruiz por blasfemo, 1560. AGN, Inquisición, vol. 16, exp. 3, ff. 125-146; Proceso contra Juan Ferrer por blasfemo, 1560. AGN, Inquisición, vol. 16, exp. 13, ff. 921-933; Proceso contra Juan Farfán por blasfemo, 1560. AGN, Inquisición, vol. 32, exp. 5, ff. 70-77; Proceso contra Diego de Ayala por blasfemo, 1560. AGN, Inquisición, vol. 32, exp. 5bis, ff. 155-165; Proceso contra Catalina de Ricalde por decir palabras contra la fe. AGN, Inquisición, vol. 32, exp. 7, ff. 176-183.

${ }^{15}$ Proceso contra Francisco Hernández ante la Inquisición ordinaria por ofensas a los franciscanos, 1556-1562 (Rubio Mañé 1942, II: 7-288). 
de los actores históricos en aquella época. ${ }^{16} \mathrm{Si}$ bien la Corona rechazó la propuesta lascasiana, es probable que la voluntad de limitar el poder de los vecinos españoles en América, claramente perceptible en las Leyes Nuevas de 1542, jugara a favor de los religiosos en los conflictos en los que se enfrentaron a los encomenderos en la década siguiente.

Ahora bien, los gobernadores mayas supieron sacar provecho de esta alianza con los franciscanos no solo para contrarrestar el poder del que gozaban los encomenderos en sus comunidades, sino también para consolidar su conocimiento de la cultura legal ibérica. Así, apenas algunos años después de iniciado el proceso de evangelización y alfabetización de los mayas, varios gobernantes se reunieron para redactar uno de los primeros documentos notariales mayas coloniales, conocido bajo el nombre de «Deslinde de los montes de Maní». ${ }^{17}$ No obstante, tanto el control que ejercían los religiosos en los pueblos mayas como el proceso evangelizador - que mermaba la cosmovisión en la que descansaba parte de la legitimidad de los gobernantes mayas - pronto originaron tensiones que resquebrajaron la alianza con los franciscanos. Estos conflictos salieron a la luz en los juicios de idolatría de 1562, durante los cuales varios gobernantes mayas fueron detenidos, torturados y castigados por los frailes con el apoyo del alcalde mayor Diego Quijada. ${ }^{18}$ En este contexto, los caciques mayas se aliaron con los encomenderos para pedir, mediante la voz del protector de los indios Diego Rodríguez de Vivanco, la expulsión de los franciscanos de Yucatán y la destitución del alcalde mayor. ${ }^{19}$ Los

\footnotetext{
${ }^{16}$ Assadourian 1990.

${ }^{17}$ Okoshi Harada 2006.

${ }^{18}$ Clendinnen 1986.

${ }^{19}$ Carta del defensor de indios Rodríguez Vivanco al rey don Felipe II, suplicándole se dignara expulsar de las Indias a los frailes de la Orden de San Francisco, Mérida, 8 de marzo de 1563 (Cartas de Indias 1877: 392-396). Véanse también las peticiones de Diego Rodríguez Vivanco en nombre de los indios de Yucatán, Mérida, 14 y 17 de septiembre de 1562 y 11 de febrero de 1563 (Scholes y Adams 1938, I: 189-232 y 240-242). Cabe señalar que, en vista de ello, la Corona mandó a castigar a los principales responsables de los procesos y ordenó que se devolviera a los indígenas el dinero en que habían estado injustamente condenados. Cédula al provincial de los franciscanos para que envíe relación de la averiguación y de los castigos a los excesos de los religiosos por la inquisición de idolatrías, 26 de febrero de 1564; y Cédula al gobernador de Yucatán
} 
vecinos españoles no solo se habían enemistado con los religiosos, quienes no dudaron en perseguir a varios de ellos ante la justicia eclesiástica, sino también con Diego Quijada, quien había abogado por una participación financiera por parte de los encomenderos en el proyecto de construcción de caminos para facilitar el transporte del tributo sin recurrir a los tamemes mayas, tal como lo habían ordenado varias cédulas reales. ${ }^{20}$

Sin embargo, la rápida secularización de los beneficios, organizada bajo el auspicio del recién llegado obispo fray Francisco de Toral, pronto incomodó a la mayoría de los gobernantes mayas. ${ }^{21}$ En efecto, los señores indígenas no tardaron en presentar ante las autoridades civiles de la provincia varias quejas en contra del mismo obispo y de varios clérigos. Si bien Matthew Restall, Pete Sigal y John Chuchiak han estudiado los conflictos que surgieron entre los mayas y sus párrocos en el Yucatán colonial, los casos más antiguos que tomaron en consideración estos autores se remontan a 1578 y 1589 . Por otro lado, los tres estudiosos analizan estos pleitos desde la perspectiva de la historia cultural, presentando las fuentes como un enfrentamiento entre violencia colonizadora y resistencia indígena. ${ }^{22}$ Pero el tratamiento desde el enfoque jurisdiccional de una serie de seis procesos fechados entre 1566 y 1567 permite aportar otra dimensión al análisis de la relación entre los mayas y el clero en el Yucatán del siglo XVI. Estos pleitos muestran que los indígenas supieron valerse de sus conocimientos legales y aprovechar las tensiones que existían entre las autoridades civiles y eclesiásticas para mantener su propio espacio jurisdiccional en el contexto colonial.

El 6 de septiembre de 1566, un indígena entregó al gobernador Luis Céspedes de Oviedo, de forma anónima, una carta en lengua maya. Este documento había sido redactado por el español Bartolomé de Bohorques, mayordomo del obispo fray Francisco de Toral, e iba dirigido «a mis queridos hijos los caciques de Chacan todos don Francisco

para que se devuelva a los indios las condenaciones que impuso fray Diego de Landa, 19 de febrero de 1565 (Solís Robleda y Bracamonte y Sosa 2011: 187-189 y 196).

${ }^{20}$ Scholes y Adams 1938, I: VIII-LX.

${ }^{21}$ Rocher Sala 2004.

${ }^{22}$ Restall 1995; Sigal 2000; y Chuchiak 2007. 
Pot, don Juan Camal, todos los caciques de Zamahil, de Hunucmá y Kinchil y Caucel y Chuburná e Itzamná». ${ }^{23}$ En el escrito, el mayordomo pedía bastimentos (gallinas, pollos, huevos, frijoles, ají y pepitas) a los caciques para los mayas que servían al obispo en la ciudad de Mérida. Se adjuntó a la mencionada carta una información en la que el mayordomo, junto con ocho testigos mayas, todos gobernadores de distintos pueblos de Yucatán, declararon que hacía más de tres años que varias comunidades indígenas enviaban comida al obispo sin paga alguna. ${ }^{24}$ Entre julio y septiembre de 1566 los mayas presentaron, ante el mismo gobernador, varias quejas en contra de fray Alonso Toral, hermano del obispo, acusándolo de haber azotado a un gran número de indios en el pueblo de Campeche y de haber tenido «acceso carnal» con varias mujeres mayas de Homún. ${ }^{25}$

El 9 de febrero de 1567, un indígena, cuya identidad no se revela en el documento, se presentó ante el alcalde ordinario de la villa de Valladolid, Juan de Villalobos, para pedir justicia. Acusó al padre Antonio Navarro de haber encarcelado a su hijo por no querer llevar una carta a Tizimín sin salario, y pidió al alcalde «que le mandase [...] soltar, pues que [su hijo] era hombre lego y no sujeto a su jurisdicción [del cura]». ${ }^{26}$ Apenas unos días más tarde, el defensor de los naturales de Valladolid,

${ }^{23}$ Traslado de la carta de Bartolomé Bohorques, mayordomo del obispo de Yucatán, Mérida, 6 de septiembre de 1566. AGI, México, 359, R. 2, N. 10, ff. 33-40. La misiva fue traducida por el intérprete Juan de Sosa.

${ }^{24}$ Los mayas que declararon fueron Francisco Pot, gobernador de Umán, Pedro Egua, gobernador de Caucel, Juan Canul, gobernador de Kinchil, Francisco Cantun, gobernador de Oxcum, Juan Canul, gobernador de Hunucmá, Francisco Canul, gobernador de Yabucu, Melchior Pech, gobernador de Chuburná y Juan Canul gobernador de Bolonpache.

${ }^{25}$ Información hecha por el gobernador para que conste que fray Alonso Toral tenían cárcel y prisiones y azotaba indios, San Francisco de Campeche, 15 de julio de 1566. AGI, México, 359, R. 2, N. 7, ff. 1-12; Información que hace el gobernador para que conste que este fray Alonso tenía acceso con algunas indias y principalmente con una casada, Mérida, 11 de septiembre de 1566. AGI, México, 359, R. 2, N. 8, ff. 1-20.

${ }^{26}$ Testimonio en que parece que el alcalde Juan de Villalobos, yendo en casa del padre Antonio Navarro a soltar cierto indio que tenía preso, fue maltratado del clérigo, Valladolid, 9 de febrero de 1567. AGI, México, 359, R. 2, N. 2, ff. 135-142. 
Antonio Borges, presentó, en nombre de los indios de Tahmuy, Tixkokob y Yaxcabá, otra queja en contra del padre Navarro, al que acusaba de no haber pagado ni a los indios que empleaba para su servicio ni a los tamemes que transportaban mercancías para él. El defensor pidió la inmediata retribución de los servicios recibidos por el cura y adjuntó a su demanda un detallado memorial en el que brindó la lista de todos los mayas que habían trabajado para el padre Navarro. ${ }^{27}$ Finalmente, en abril de 1567, tres mayas del pueblo de Chancenote, Francisco Cima y Pablo May, alguaciles, y Francisco Balam, principal, parecieron ante Juan de Villalobos para quejarse de los agravios del padre Ruy Pérez de Brito. Según los querellantes, el cura había obligado a las autoridades mayas de Chancenote a que le compraran una botija de vino por el precio de veinte tostones y, en cuanto este recibió el dinero, se la quitó. Posteriormente, utilizó la misma práctica fraudulenta en al menos otros cuatro pueblos: Yxmucul, Tijolopo, Tequeaque, Tiscancancal. ${ }^{28}$ Los litigantes mayas ańadieron que el padre Brito había azotado al mayordomo de la cofradía de Chancenote, Pedro Be, por haberle pedido «carta de pago de cómo los tomaba [ciertos tostones] para dar la cuenta de ellos y de su mayordomía». ${ }^{29}$

Es imprescindible vincular aquellos pleitos con las cartas, redactadas en maya y en castellano, que varios caciques de Yucatán enviaron a Felipe II en 1567. Entre el 11 de febrero y el 5 de marzo se escribió una serie de siete misivas, de formato y contenido similares, que fueron firmadas por diferentes caciques, gobernadores, batabes y alcaldes mayas. En estos documentos los mayas pidieron al monarca español el regreso de los

${ }^{27}$ Queja presentada ante Juan de Villalobos por Antonio Borges, defensor de los naturales, contra el padre Antonio Navarro y memoria de ciertos reales que dizque debe el padre Navarro a los indios que tiene a cargo, Valladolid, 25 de febrero de 1567. AGI, México, 359, R. 2, N. 2, ff. 129-134.

${ }^{28}$ Relación presentada ante Juan de Villalobos contra el padre Ruy Pérez de Brito, cura de Chancenote, sobre cómo vendía vino a los indios con condición que se las volviesen y azotó a un mayordomo de los indios porque le pedía carta de pago de ciertos tostones, Valladolid, 3 de abril de 1567. AGI, México, 359, R. 2, N. 2, ff. 125-127.

${ }^{29} \mathrm{Ib}$. 
franciscanos expulsados en $1563 .{ }^{30} \mathrm{El} 9$ de marzo del mismo año, varios gobernadores mayas volvieron a escribir al rey y, además de presentar la misma solicitud, acusaron al clero secular de ser interesado en "tratos y contratos», de dar mal ejemplo a los naturales y de no hablar la lengua maya. ${ }^{31}$ El estudio lingüístico, paleográfico y diplomático que realizó Zoraida Raimúndez Ares del corpus de siete cartas le permitió demostrar que la versión castellana de la carta sirvió de modelo «a partir del cual se redactaron los documentos en maya; de ahí que las diferencias entre los documentos se encuentren únicamente en el maya y no en el castellano». ${ }^{32}$ Por otro lado, William Hanks observó que el origen de los firmantes de cada ejemplar se correspondía con la organización territorial impuesta por los franciscanos, de modo que dedujo que «la estructura de la guardianía fue un vector de la acción colectiva» para los mayas. ${ }^{33}$ Raimúndez Ares también considera que la «coordinación no provino de parte de los caciques yucatecos, sino de los religiosos franciscanos, quienes ordenaron directa o indirectamente la realización de estas cartas distribuyendo por las áreas de realización de las epístolas un documento modelo en castellano».34 Para ambos autores, estos documentos expresan, por tanto, reivindicaciones franciscanas. No obstante, la estrecha relación que existe entre las misivas y los seis pleitos de 1566 y 1567 invita a matizar estas interpretaciones.

Estos procesos, en efecto, fueron el resultado de iniciativas individuales y colectivas emprendidas por actores mayas, que no solamente presentaron

${ }^{30}$ Carta de los caciques indios de Yucatán, 11 de febrero de 1567, Archivo Histórico Nacional de Madrid [en adelante AHN], Diversos-Colecciones, 24, N.77, ff. 1-2. Cartas de los caciques indios de Yucatán, 11 y 12 de febrero y 5 de marzo de 1567. AGI, México, 367, ff. 62-71 y ff. 88-89.

${ }^{31}$ Carta de los indios de Yucatán a Su Majestad, Mérida, 9 de marzo de 1567. AGI, México, 359, R. 2, N. 10, ff. 13-22.

32 Raimúndez Ares 2016: 36.

${ }^{33}$ Hanks 2010: 319-321.

${ }^{34}$ Raimúndez Ares 2016: 36. Según Hanks, la carta del 9 de marzo de 1567 también contiene «una fuerte voz franciscana, lo que apunta a que los frailes participaron en la redacción del documento o, al menos, que sus instrucciones brindaron los parámetros en los cuales el clero secular fue valorado» (Hanks 2010: 315-326). 
quejas, sino también pruebas materiales (como la carta del mayordomo del obispo), detallados memoriales (como la cuenta de los gastos ocasionados por los servicios ofrecidos al padre Navarro) y numerosos testimonios orales. Por otro lado, estas acciones legales fueron realizadas, de forma independiente, en diversos espacios — Campeche, Mérida, Valladolid-y dirigidas en contra de diferentes clérigos claramente identificados —el mismo obispo, fray Alonso Toral, el padre Antonio Navarro y el padre Ruy Pérez de Brito- - Los pleitos también muestran que los mayas se comunicaron entre sí y que supieron organizarse más allá de los límites de cada una de sus comunidades. Así lo sugieren tanto la averiguación realizada por los querellantes de Chancenote, quienes brindaron al alcalde ordinario de Valladolid informaciones sobre otros cuatro pueblos extorsionados por el cura Pérez de Brito, como el memorial de los servicios que los mayas prestaron al padre Navarro, el cual incluía datos procedentes de tres pueblos diferentes. Las cartas de 1567 retomaron y sintetizaron el contenido de todos los pleitos, poniendo de manifiesto un nivel aún superior de movilización por parte de los actores mayas.

Así, pues, las siete cartas de 1567 reúnen un total de 69 firmas, de las cuales, según el análisis paleográfico de Raimúndez Ares, 35 fueron individuales, mientras que otras 7 personas realizaron grupos de entre 2 y 12 firmas. ${ }^{35}$ Esto significa que al menos 42 mayas estuvieron presentes cuando circularon las cartas por los pueblos de indios y que el mismo número de individuos fue capaz de firmar los documentos, un nivel de participación indígena difícil de alcanzar si la iniciativa de esa campaña hubiese sido únicamente orquestada por los franciscanos. En resumidas cuentas, aunque es probable que los franciscanos elaboraran el documento en castellano que sirvió de modelo a las versiones mayas, no se puede minimizar el papel que desempeñaron los mayas no solamente en términos de libre y masiva adhesión a la crítica contra el clero secular, sino también en el proceso de circulación y traducción del documento. La carta del 9 marzo de 1567, con 25 firmas - 14 de ellas fueron individuales, mientras que las 11 restantes han sido atribuidas a

${ }^{35}$ Raimúndez Ares 2016: 160-162. 
solo 2 personas diferentes—, apunta en la misma dirección. ${ }^{36}$ Además, Raimúndez Ares señala que, en este caso, el documento original fue la versión maya, puesto que el escribano maya, al no tener «necesidad de adaptarse a un modelo en castellano, emplea un tipo de escritura menos forzada». ${ }^{37}$ Ahora bien, esta misiva es precisamente la que contiene la descripción más detallada de las exacciones del clero secular, lo que confirma que los mayas fueron los autores de este informe.

Es interesante notar, asimismo, que las autoridades mayas de la región de Maní no se unieron a las peticiones de los demás caciques de la provincia, pese a que Maní fuera cabecera de una guardianía controlada por los franciscanos. Al contrario, en una misiva del 12 de abril de 1567, cuatro signatarios mayas de esta región se opusieron al regreso de los franciscanos que habían participado en los juicios de idolatría de 1562, dado que los caciques todavía esperaban que el rey los castigara por los delitos que habían cometido. ${ }^{38}$ Los signatarios denunciaban que los religiosos «nos traen tan avasallados hasta quitarnos nuestro señorio que heredamos de nuestros antepasados, cosa que nunca padecimos en nuestra gentilidad». ${ }^{39}$ En realidad, este amplio conjunto documental, conformado tanto por las cartas como por los pleitos, demuestra que los mayas buscaron el amparo de la justicia real —el gobernador de Yucatán, el alcalde ordinario y el defensor de indios de Valladolid, y el mismo monarca - para defender su jurisdicción e intereses frente a las intromisiones y excesos del clero, ya fuera regular o secular. Así pues, en la misiva del 9 de marzo de 1567, las autoridades mayas se quejaban de que los clérigos «nos prendian sin pedir auxilio a vuestra justicia real». ${ }^{40}$ Los caciques mayas eran conscientes de que la posibilidad de que sus preten-

36 Ib.: 163 .

${ }^{37}$ Ib.: 37.

${ }^{38}$ Carta de los indios gobernadores de varias provincias de Yucatán al rey don Felipe II quejándose de los tormentos, muertes y robos que con ellos habían cometido los religiosos de la orden de San Francisco, Yucatán, 12 de abril de 1567, AHN, Diversos Colecciones, 25, N. 2, ff. 1r-2v.

${ }^{39} \mathrm{Ib}$. El énfasis es mío.

${ }^{40}$ Carta de los indios de Yucatán a Su Majestad, Mérida, 9 de marzo de 1567. AGI, México, 359, R. 2, N. 10, ff. 13-22. El énfasis es mío. 
siones tuviesen éxito dependía, en gran medida, de que su actuación se insertara en el contexto de rivalidad que oponía no solo al clero secular con el regular, sino también a las autoridades civiles con las eclesiásticas. ${ }^{41}$

De hecho, el alcalde ordinario de Valladolid se fue personalmente hasta el pueblo de Tecuche para exigir al padre Navarro que soltara al indio que tenía preso y, frente a la negativa del clérigo, se lo «tornó a requerir diciendo 'váyase, padre, con Dios y entienda en su jurisdicción y no en la mía’. Pero el cura reaccionó violentamente, ya que, según los testigos, «entró en su retraimiento y tomó una espada y una rodela y salió con la espada desnuda y se vino a por el señor alcalde», de modo que el alcalde Villalobos decidió remitir el expediente tanto al obispo como al gobernador. ${ }^{42}$ Ahora bien, la activa participación de los mayas en el sistema de justicia resultó determinante en el conflicto entre el gobernador Luis Céspedes de Oviedo y el obispo fray Francisco de Toral. En efecto, el primero supo utilizar hábilmente las denuncias indígenas para tratar de mermar la jurisdicción eclesiástica y consolidar la real, esto es, la suya propia. Esta dimensión aparece en el pleito contra fray Alonso Toral, donde Céspedes de Oviedo denunció que algunos religiosos, clérigos y personas eclesiásticas, «desacatada y atrevidamente en menosprecio de los proveimientos reales», hicieron

prender, azotar y trasquilar y ejecutaban y hacían otros castigos en muchos indios e indias de estas provincias, lo cual hacian de su propia autoridad algunos de ellos y otros so color de que tenían las veces y poder del obispo y jueces eclesiásticos de este obispado y sin preceder auxilio real que se pida ni haya pedido a la justicia real [...], todo a efecto de tener superioridad $y$ mando sobre los indios. ${ }^{43}$

${ }^{41}$ Estas rivalidades perduraron a lo largo del periodo colonial, como lo sugieren obras como el Informe contra Idolarum Cultores del Obispado de Yucatán (Madrid, 1639) de Pedro Sánchez de Aguilar, en el que el autor trató de reforzar la jurisdicción eclesiástica en detrimento de la civil en los delitos contra la fe cometidos por la población indígena. 42 Testimonio en que parece que Juan de Villalobos, yendo en casa del padre Antonio Navarro a soltar cierto indio que tenía preso, fue maltratado del clérigo, Valladolid, 9 de febrero de 1567. AGI, México, 359, R. 2, N. 2, ff. 135-142.

${ }^{43}$ Información contra fray Alonso Toral, San Francisco de Campeche, 15 de julio de 1566. AGI, México, 359, R. 2, N. 7, f. 2. El énfasis es mío. 
Así pues, el 19 de marzo de 1567 el gobernador Luis Céspedes de Oviedo despachó un auto y pregón donde prohibió que «el obispo y sus jueces proced[ieran] contra los indios" y dio "por ningunos los procesos que contra ellos hubieren hecho». ${ }^{44}$ Queda claro, por ende, que las pretensiones de los mayas, que consistían en limitar el poder de los clérigos en sus comunidades, fueron satisfechas. Pero también es cierto que el gobernador trató de aprovechar la situación para consolidar su propio poder en la provincia, de modo que, el 2 de mayo del mismo año, promulgó detalladas ordenanzas para los pueblos de indios. ${ }^{45}$ Pero esta medida revestía, en realidad, un valor esencialmente simbólico, puesto que sus esporádicas visitas no permitían al gobernador ejercer un control efectivo en las comunidades indígenas. ${ }^{46}$ Conviene señalar, asimismo, que las enérgicas decisiones del gobernador fueron apoyadas por los vecinos españoles, quienes, en una carta del 9 de mayo de 1567, pidieron a Felipe II que diera

facultad al que en estas provincias gobernare para que pueda alzar fuerza cuando lo haya menester, como lo puede hacer la Real Audiencia, y cuando esto lugar no haya mande Vuestra Majestad proveer su real cédula y por ella mande al obispo y a sus provisores y vicarios que no puedan tener excomulgados a ningún juez ni a mero lego particular más tiempo de tres días. ${ }^{47}$

El conflicto con el clero también tenía que ver con la voluntad del obispo Francisco de Toral de que los encomenderos de Yucatán pagaran el diezmo sobre los productos de algodón y las gallinas. Para tratar de vencer la fuerte resistencia que opusieron los vecinos, varios clérigos de la provincia se negaron a administrarles la confesión tanto en Valladolid como en Mérida. ${ }^{48}$

${ }^{44}$ Pregón y diligencias del gobernador para que el obispo y sus jueces no procedan contra los indios, Mérida, 19 de marzo de 1567. AGI, México, 359, R. 2, N. 2, ff. 149-151.

${ }^{45}$ Ordenanzas que hizo Luis Céspedes de Oviedo para el buen gobierno de los naturales, Mérida, 2 de mayo de 1567. AGI, México, 359, R. 2, N. 2, ff. 104-114.

${ }^{46}$ Sobre las visitas, véanse Sánchez Bella 1991 y Guibovich Pérez 2011.

${ }^{47}$ Información del consejo de la ciudad de Mérida de los agravios que reciben del obispo y sus jueces excomulgando al gobernador y jueces seglares y personas seculares por muy livianas cosas, Mérida a 9 de mayo de 1567. AGI. México, 359, R. 2, N. 2, ff. 153-156. 48 Testimonio de que el obispo mandó hacer requerimiento al gobernador que repusiese lo que había hecho cerca de confesarse los vecinos, Mérida, 27 de febrero de 1567. AGI, 
En definitiva, los documentos de 1566 y 1567 revelan el profundo conocimiento que tenían los mayas del funcionamiento de los tribunales civiles y eclesiásticos, de los conflictos jurisdiccionales que oponían a varios sectores de la población hispana, de las cédulas más recientes proveídas por la Corona espańola y, de manera general, de la retórica jurídico-legal vigente en el Imperio hispánico. La carta de marzo de 1567 sugiere, por ejemplo, que los mayas debieron de haber tenido acceso a la cédula de 1565 en la que la Corona dispuso que los párrocos hablaran las lenguas autóctonas usadas en sus doctrinas. ${ }^{49} \mathrm{Si}$ bien es cierto que los franciscanos fueron unos de los principales vectores mediante los cuales los indígenas tuvieron acceso a la cultura legal colonial, este papel de mediación no implicó que los mayas siempre se adhirieran a su posición política. ${ }^{50}$ Es probable, en efecto, que el apoyo que manifestaron los caciques hacia los franciscanos en las cartas de febrero y marzo de 1567 revistiera una dimensión estratégica. Con dicho apoyo, buscaban reforzar su ataque contra el obispo y el clero secular, defender su propia jurisdicción en los pueblos de indios y mantener el control de la mano de obra y de los excedentes de mercancías producidos en sus comunidades. La alianza con el acalde ordinario de Valladolid y el gobernador de Yucatán fue, asimismo, estratégica. La denuncia contenida en la carta de abril de 1567, donde los signatarios mayas afirmaron que Céspedes de Oviedo «nos ha aumentado tribulaciones, llevándonos a nuestras hijas y mujeres a servir a los espańoles contra su voluntad y nuestra", no deja dudas al respecto. ${ }^{51}$

Tanto esas alianzas como la intensa actividad epistolar y legal de los actores mayas no fueron ajenas a la decisión de la Corona de que fray

México, 359, R. 2, N. 2, ff. 147-148; Testimonio para que conste que el padre Navarro no confesó a algunas personas, Valladolid, 1567. AGI, México, 359, R. 2, N. 2, ff. 143-146. ${ }^{49}$ Real cédula a los obispos de Nueva Espańa ordenando que solamente envíen a los pueblos de indios clérigos conocedores de los idiomas como párrocos, Buen Grado, 22 de mayo de 1565 (Solano 1991: 65). Sobre el uso del argumento lingüístico como razón para la expulsión de los clérigos de las doctrinas, véase Cobo Betancourt 2014.

${ }^{50}$ Cunill 2015a; y Zaballa Beascoechea 2011a.

${ }^{51}$ Carta de los indios gobernadores de varias provincias de Yucatán al rey Felipe II, 12 de abril de 1567. AHN, caja 3. 
Diego de Landa regresara a Yucatán en calidad de obispo en $1573 .{ }^{52}$ Pero esto no impidió que, en la década de 1570, varios gobernadores indígenas compraran al escribano Rodrigo Fránquez copias de una provisión en la que el Consejo de Indias prohibía que los religiosos infligiesen castigos físicos a los indios. ${ }^{53}$ Según la Audiencia de México, el escribano "había llevado a los indios gran suma de pesos de oro de su propia autoridad» gracias a este comercio fraudulento, puesto que cobraba «a cada pueblo diez tostones por cada traslado». Los oidores ańadían que la difusión de este documento "había sido causa que ellos [los indios] ya no acudiesen a la doctrina ni al sermón con el cuidado que solían hacer y había sido perturbación de la doctrina cristiana». ${ }^{54}$ No cabe duda de que los gobernadores mayas usaron la cédula que habían comprado a Rodrigo Fránquez para mermar la autoridad de los frailes en el seno de sus comunidades.

Sin embargo, en el mismo momento, el nombramiento de corregidores por el nuevo gobernador de Yucatán, Francisco Velázquez de Gijón, generó la oposición conjunta y probablemente coordinada de los gobernadores mayas, representados por su defensor, los franciscanos y los cabildos españoles. ${ }^{55}$ El corregimiento simbolizaba la jurisdicción real y, concretamente, los intereses del gobernador en el ámbito local. No extraña, por ende, que la figura del corregidor generara tensiones, ya que los actores, tanto mayas como espańoles, entendieron que su presencia podría llegar a mermar su propia jurisdicción. Así, pues, en 1573, el defensor de indios Francisco Palomino pidió la destitución de los corregidores, insistiendo en la capacidad de los cabildos mayas para

${ }^{52}$ Cédula para que se dé posesión a fray Diego de Landa del obispado de Yucatán, 19 de enero de 1573 (Solís Robleda y Bracamonte y Sosa 2011: 260-261).

${ }^{53}$ Es probable que se tratara de la real cédula para que los religiosos no se entremetan a hacer prisiones a ningún indio ni los azoten, Toledo, 4 de septiembre de 1560 (Puga 1945, II: 348-349). Sobre el contexto en el que se promulgo este texto, véase Ruiz Medrano 2002.

${ }^{54}$ Real provisión dada por la Real Audiencia de México, 22 de agosto de 1576. AGI, México, 101, R. 3, 5 ff.

${ }^{55}$ Conflictos similares se produjeron tanto en la ciudad de México como en los Andes en los mismos años. Quijano 2016. Agradezco al autor la oportunidad que me dio de consultar su manuscrito (Puente Luna 2016). 
desempeñar las funciones de gobierno y justicia en sus pueblos. Argüía que era suficiente que los «naturales de estas provincias se estén con el gobierno de sus caciques sin que se les ponga otra justicia, porque lo demás es dar la ocasión a que les lleven sus haciendas». ${ }^{56}$ En una petición de 1579, el defensor volvió a afirmar que los indios estaban «bien gobernados por sus caciques [gobernado]res indios y sin la costa y molestia que [los corregidores] les hacen». ${ }^{57}$

El obispo fray Diego de Landa y los procuradores de los cabildos de Mérida y Valladolid se unieron a la campańa contra el corregimiento. En una carta de 1578, el obispo lamentaba que el gobernador Guillén de las Casas hubiese «hinchado esta provincia de corregidores entre los indios sin salario y algunos de ellos hombres muy pobres y que necesariamente han de hacer agravios y vejaciones a los indios para sustentarse». ${ }^{58} \mathrm{Ya}$ en 1573 el procurador de Mérida, Pedro Hernández Nieto, pidió al Consejo de Indias la destitución de los jueces comisionados que había designado el gobernador Diego de Santillán. Según él, no convenía que los «jueces comisionados anden por los pueblos de los naturales de que reciben gran vejación». ${ }^{59}$ En 1579, el procurador de Valladolid, Gutierre López, también exigió la suspensión no solo de todos los corregidores, sino también del alcalde mayor designado por el gobernador Guillén de las Casas. Consideraba que este oficial impedía que el fiel ejecutor, nombrado por el cabildo de esta villa, hiciese su trabajo; a saber, «proveer a la dicha villa y vecinos de ella de bastimentos y de mantenimientos de las cosas necesarias que

${ }^{56}$ Carta de Francisco Palomino al rey, Mérida, 28 de marzo de 1573, en el pleito de Carlos Arellano con Francisco Palomino sobre la carta que escribió a Su Majestad en deshonor de dichas provincias, 1579. AGI, Justicia, 1016, N. 11, ff. 1150-1155.

${ }^{57}$ Francisco Palomino suplica se le dé sobrecédula de la que está dada para que el gobernador de aquella provincia no tenga más de un teniente letrado y quite los corregidores y alcaldes mayores que tiene puestos, 1579. AGI, Indiferente General, 1390. El documento está roto en los bordes, por lo que las palabras entre corchetes son sugerencias en consideración del sentido del fragmento.

${ }^{58}$ Carta de fray Diego de Landa al rey, Mérida, 12 de marzo de 1578. AGI, México, 369, f. 252.

${ }^{59}$ Petición presentada ante el gobernador Diego de Santillán por el procurador del cabildo de Mérida contra los jueces comisionados, Mérida, 2 de septiembre de 1573. AGI, México, 369, ff. 7-9. 
son menester en ella, lo cual hace que traigan los indios de la comarca y término de la dicha villa como siempre se ha hecho». ${ }^{60}$ Una vez más, lo que estaba en juego en los conflictos en torno al oficio de corregidor era el poder que pretendían ejercer distintas autoridades sobre la población maya. Pero, si bien queda claro que el control local constituyó una de las claves en las luchas de poder, la otra fue la representación jurídica, esto es, la necesidad, por parte de los actores, de estar adecuadamente representados en los foros de justicia del Imperio hispánico. En efecto, fue en los tribunales donde interactuaron los cuerpos sociales, se resolvieron los conflictos y se articularon entre sí las distintas jurisdicciones que componían el complejo entramado político de la Monarquía hispana.

\section{REPRESENTACIÓN JURÍDICA Y ARBITRAJE EN LOS FOROS DE JUSTICIA DEL IMPERIO}

El juicio por rebelión que se abrió en contra del maya Andrés Cocom en 1589 muestra que el sistema de justicia funcionaba según un principio acumulativo, que permitía integrar y articular distintas jurisdicciones. El 9 de abril de 1589, el alcalde maya don Jorge Canul fue alertado del comportamiento sospechoso de algunos vecinos del pueblo de Tenabo. Canul se abocó a recoger las declaraciones de varios testigos y a confiscar pruebas materiales, como las cartas que intercambiaron los acusados y parte del dinero, cacao y cera que habían sido recolectados en una derrama a favor de Andrés Cocom, acusado de preparar una rebelión. El alcalde maya también envió misivas a los demás gobernadores indígenas de la zona, recomendándoles que vigilaran a los habitantes de sus comunidades. Después de ello, don Jorge Canul viajó a la villa de San Francisco de Campeche, donde ofreció una declaración ante los alcaldes ordinarios y les entregó las pruebas que había confiscado. ${ }^{61}$ Los alcaldes

${ }^{60}$ Petición del procurador del cabildo de Valladolid ante el Consejo de Indias, 1579. AGI, Indiferente General, 1390.

${ }^{61}$ Declaración de don Jorge Canul ante los alcaldes ordinarios de Campeche, Campeche, 17 de abril de 1589 (Quezada y Torres Trujillo 2010: 143-149). Sobre este intento de rebelión, véanse Gorissen 2007 y Cunill 2015b. 
utilizaron el material entregado, junto con nuevos testimonios y las confesiones de los acusados, en el juicio criminal que abrieron contra Andrés Cocom y sus cómplices. ${ }^{62}$ Todo ello indica que los oficiales del cabildo maya ejercieron plena jurisdicción sobre sus pueblos, ya que tenían la facultad para convocar a testigos, confiscar pruebas, detener a los sospechosos y comunicarse con otras autoridades, tanto indígenas como españolas; además, sus gestiones fueron tomadas en cuenta en otros foros de justicia. En efecto, en sus ordenanzas de 1583, García de Palacio estipuló que

los dichos alcaldes conocerán en todos los casos civiles y criminales que en el dicho pueblo se ofrecieren [...] con que no sea en caso de mucha importancia o delito que merezca pena de muerte, ni en las causas civiles de cuatro pesos arriba, porque éstas se han de remitir al gobernador de esta provincia o su lugarteniente, mas podrán hacer la información, prender a los culpados y después remitirán la causa a los dichos jueces españoles. ${ }^{63}$

Por otro lado, es importante subrayar que el que el pueblo de Tenabo se encontrara en la jurisdicción del corregimiento de Maní no supuso ningún problema en la resolución del caso. Así, en el mismo momento en el que don Jorge Canul realizaba sus averiguaciones en Tenabo, el corregidor Juan de Sanabria, quien también se había enterado de la intención de rebelarse de Andrés Cocom, confeccionó su propia información. Este documento fue enviado al gobernador Antonio de Vozmediano, quien ordenó a su teniente ir hasta Calkiní a abrir el juicio criminal en contra de los supuestos rebeldes. De esta manera, se abrió un nuevo proceso en el que se acumularon la declaración de don Jorge Canul y las pruebas que había confiscado, el pleito iniciado por los alcaldes ordinarios de Campeche y la información del corregidor de Maní. ${ }^{64}$ En otras palabras, los trámites realizados por el gobernador de Tenabo, el corregidor de

${ }^{62}$ Testimonio del escribano público Luis de Torres acerca del juicio criminal en contra de Andrés Cocom, Mérida, 13 de mayo de 1604. AGI, Patronato, 20, N. 5, R. 25 , ff. 54-65.

${ }^{63}$ García Bernal 1985: 8.

${ }^{64} \mathrm{Ib}$. 
Maní y los alcaldes ordinarios de Campeche llegaron a formar parte de este voluminoso pleito. No cabe duda de que este último, metáfora de la justicia real, permitía articular las jurisdicciones entre sí, convirtiéndose en el símbolo de la participación colectiva, una dimensión que volvía a aparecer en los castigos, ya que muchas veces estos eran públicos. Por lo tanto, comprender el funcionamiento de los foros de justicia y el proceso de arbitraje de los conflictos resulta fundamental para conocer el peso político del que gozaban los distintos actores políticos en el Imperio hispánico.

Como ya se ha visto, en el Yucatán colonial los conflictos civiles y criminales debían resolverse en el juzgado del gobernador. ${ }^{65} \mathrm{Al}$ ser nombrado directamente por el monarca, con quien mantenía una relación institucionalizada mediante el intercambio de cartas y cédulas, el gobernador representaba la justicia real. Aunque en principio cualquier persona podía presentarse en las audiencias que presidía el gobernador para pedir justicia, la mediación legal fue corriente en este tribunal. En efecto, los cabildos espańoles tenían facultad para elegir anualmente, entre los alcaldes ordinarios o los regidores que acababan dejar su cargo, a un procurador que representara sus intereses. ${ }^{66}$ Por su parte, a partir de la década de 1550, los cabildos indígenas se beneficiaron de un sistema de representación jurídica institucionalizado gracias al nombramiento de defensores de indios. ${ }^{67}$ El pleito sobre el transporte de mercancías por los tamemes mayas, que analizaremos a continuación, muestra que los procuradores de los cabildos españoles y los defensores de indios fueron personajes ubicuos en las audiencias del gobernador de Yucatán y que la representación jurídica fue determinante en la resolución de los conflictos que involucraban a la población indígena en el Imperio hispánico. ${ }^{68}$

${ }^{65}$ Acerca de los tribunales eclesiásticos, véanse Zaballa Beascoechea 2011b; Traslosheros y Zaballa Beascoechea 2010; Traslosheros 2002; y Chuchiak 2000.

66 Bayle 1952: 225-261.

${ }^{67}$ Borah 1985; Cunill 2012a; y Solís Robleda 2013.

${ }^{68}$ Pleito de Francisco Palomino con la ciudad de Mérida y encomenderos sobre que no se carguen los indios, 1579. AGI, Justicia, 1016, N. 10. 
Desde la década de 1550, la Corona española había prohibido que se usara a la población maya para el transporte de mercancías en Yucatán. ${ }^{69}$ Pero, cuando asumió su cargo, el defensor Francisco Palomino comprobó que los tamemes seguían cargándose contra su voluntad a cambio de una remuneración mínima o, incluso, inexistente. Por consiguiente, en 1572, el defensor pidió al gobernador Francisco Velázquez de Gijón que mandara ejecutar la normativa real. En vez de ello, este entregó una copia de la petición del defensor al procurador de Mérida, cuya intervención - y la de sus sucesores - alargó los trámites legales durante varios años y obstaculizó el cumplimiento de las órdenes reales. ${ }^{70} \mathrm{Al}$ comprobar que el gobernador aplazaba la ejecución de la normativa real, el defensor elevó su queja ante la Audiencia de México, donde el procurador Agustín Pinto representó a los mayas y obtuvo, en 1574, la promulgación de una provisión para que no se cargara a los indios. ${ }^{71}$ No obstante, en el ínter, el gobernador Francisco de Gijón había realizado una información en Maní, en la cual preguntó a los caciques mayas si querían que se transportara el tributo «conforme a lo que Su Majestad en este caso tiene proveído y mandado, que es y se entiende llevarlos en yeguas y en carretas y no en indios cargados, por la vejación que los naturales por ello podían recibir». ${ }^{72}$ Los gobernadores mayas contestaron que, al no disponer de caballos y mulas, ni de medios financieros suficientes para comprarlos y criarlos, preferían seguir recurriendo a los tamemes para transportar el tributo. Francisco de Gijón se valió de este documento

${ }^{69}$ Real cédula a la Audiencia de los Confines para que se cumpla en Yucatán la cédula de 22 de febrero de 1549 sobre el servicio personal de los indios, 9 de septiembre de 1551 (Solís Robleda y Bracamonte y Sosa 2011: 115-117). En 1558, la Audiencia de Guatemala dispuso que los mayas solo podrían transportar comida «en los casos que a él [alcalde mayor] le pareciere que conviene y es necesario». Provisión de la Audiencia de los Confines sobre cargar a los indios de Yucatán, 28 de abril de 1558 (Solís Robleda y Bracamonte y Sosa 2011: 152).

70 Tau Anzoátegui 1980.

${ }^{71}$ Provisión de la Real Audiencia de Nueva Espańa, México, 17 de septiembre de 1574. AGI, Justicia, 1016, N. 10, ff. 920v-926v.

${ }^{72}$ Respuesta de la provincia de Maní sobre el traer de los tributos, 23 de septiembre de 1574. AGI, Justicia, 1016, N. 10, ff. 881r-891v. 
para negarse a cumplir la provisión de la Real Audiencia. ${ }^{73}$ Sin embargo, el defensor señaló que, si bien la información era formalmente válida, su contenido era engañoso, puesto que el gobernador dejó entender a los indios que los costos del transporte del tributo debían correr a su cargo. En estas circunstancias, el proceso llegó ante el Consejo de Indias en grado de apelación en 1576.

En realidad, la necesidad de recurrir a la Real Audiencia de México y, en última instancia, al Consejo de Indias se explica por la colusión de intereses entre los gobernadores de Yucatán y los miembros del cabildo de Mérida. ${ }^{74}$ En efecto, si bien los cabildos se negaron a que los gobernadores se entrometieran en su jurisdicción local y se opusieron firmemente al nombramiento de tenientes de gobernadores, corregidores o jueces de comisión, no dudaron en trabar alianzas con la máxima autoridad de la provincia para defender sus intereses económicos. Para que el Consejo contara con la información suficiente para emitir una sentencia, las partes en contienda tuvieron que entregar dos probanzas. El defensor de indios Francisco Palomino preparó un interrogatorio de 21 preguntas, a las que contestaron 35 testigos, de los cuales 15 fueron españoles y 20, mayas; todos desfavorables a que los tamemes transportaran las mercancías. ${ }^{75}$ Por su lado, el procurador de Mérida redactó un interrogatorio de 18 preguntas, destinado a demostrar lo contrario: recogió los testimonios de 3 españoles y de 7 indígenas y agregó a esta información un documento firmado por 11 gobernadores mayas. ${ }^{76}$ En la Corte espańola, los

${ }^{73}$ Respuesta de Francisco de Gijón a la petición de Francisco Palomino, 26 de febrero de 1575. AGI, Justicia, 1016, N. 10, f. 929v.

${ }^{74}$ Cabe recordar que, desde su origen, la institución del cabildo español y el oficio de gobernador estuvieron vinculados, dado que fueron los 'adelantados' quienes nombraron a los primeros cabildantes. Si bien este vínculo se fue debilitando con el paso del tiempo, puesto que los gobernadores eran nombrados por el rey y se les prohibió emparentarse con la oligarquía local, la colusión de intereses entre gobernadores y cabildos espańoles fue frecuente.

${ }^{75}$ Interrogatorio y testigos presentados por Francisco Palomino, Mérida, 6 de marzo de 1576. AGI, Justicia, 1016, N. 10, ff. 964r-1063v.

${ }^{76}$ Interrogatorio y testigos presentados por Martín de Palomar, Mérida, 1 de marzo de 1576. AGI, Justicia, 1016, N. 10, ff. 1064v-1116v. 
procuradores Sebastián de Santander y Alonso de Herrera representaron, respectivamente, a los mayas y al cabildo de Mérida.

Cabe señalar que, pese a las reiteradas peticiones, la Corona española siempre se negó a que los cabildos, ya fueran españoles o indígenas, gozaran de una representación jurídica institucionalizada en la Corte. Esto obligó a que los actores encontraran alternativas para defender sus intereses ante el Consejo de Indias. La solución radicó en la circulación de los representantes legales entre América y España y en el otorgamiento de poderes a procuradores de causas en el Consejo de Indias. ${ }^{77}$ Así pues, a lo largo del proceso sobre el transporte del tributo, la representación legal se convirtió en un auténtico reto para las partes. Prueba de ello es que el viaje a la Corte que debía supuestamente realizar el defensor fue causa de que los cabildantes de Mérida lo encarcelaran en 1576. Se rumoreaba que «el provincial de los religiosos y yo [Palomino] habíamos ido a una provincia que llaman de Tizimín y que habíamos sacado de las cajas de las comunidades de los indios gran suma de dinero para que yo fuese a Espańa». ${ }^{78}$ Ahora bien, en 1578, Francisco Palomino y Carlos de Arellano se encontraban en España para representar los respectivos intereses de los indios de Yucatán y del cabildo de Mérida. ${ }^{79}$ No era la primera vez que los cabildos españoles de la provincia enviaban a sus procuradores a la corte del rey. Según Francisco Palomino, en 1574, el Cabildo de Mérida recolectó «gran suma de pesos de oro para enviar un

77 En 1555, Las Casas comparaba la situación de los indios, «desamparados, sin que nadie viniese a defenderlos», con la de los espańoles, que tenían los medios financieros para enviar a sus procuradores ante el rey. Carta al maestro fray Bartolomé Carranza de Miranda, 1555 (Las Casas 1995: 280 y 303). En 1570, el doctor Cáceres pidió a Juan de Ovando que cada tres ańos el rey hiciera "Cortes con los procuradores de las ciudades y provincias de estas partes y reinos [...] y estando a un tiempo juntos los procuradores de las provincias, se entenderán mejor las cosas de estas partes y [...] se despacharán en pocos días muchos negocios» (Bayle 1952: 238-240).

${ }^{78}$ Carta de Francisco Palomino al rey, Mérida, 20 de febrero de 1576. AGI, México, 101, R. 2, 2 ff.

${ }^{79}$ Petición de los indios de Yucatán presentada en el Consejo de Indias por Sebastián de Santander, Madrid, 20 de septiembre de 1578. AGI, Justicia, 1016, N. 10, f. 891. 
procurador con los negocios contra él [obispo fray Diego de Landa] a tratarlos con Vuestra Majestad». ${ }^{80}$

El financiamiento de los desplazamientos de defensores, procuradores y representantes legales en la Audiencia de México o en el Consejo de Indias fue tan determinante como polémico. A este propósito, conviene subrayar que parte de los gastos de justicia relacionados con la contratación de un procurador en la Audiencia de México recayó en las comunidades mayas de Yucatán. Por otro lado, fue el obispo fray Diego de Landa quien, en 1578, pagó el viaje del defensor Francisco Palomino a España. ${ }^{81}$ No obstante, la participación financiera de los indígenas parece haber sido voluntaria, ya que, en la información de 1576, fray Pedro Calderón declaró que había visto cómo los caciques de la guardianía de Tecanto dijeron a Francisco Xool, «hombre de mucha razón, que siguiese esta causa y pleito, que si fuese necesario le ayudarían con sus haciendas aunque quedasen desnudos». ${ }^{82}$ Todo ello sugiere que los mayas eran conscientes de la importancia de obtener fallos favorables en los pleitos en que sus intereses estaban en juego y que estaban dispuestos a invertir dinero en los gastos relacionados con los trámites judiciales. ${ }^{83}$ A la cuestión de la representación jurídica y a las estrategias legales también fue aunado el recurso a la violencia para obstaculizar el correcto desenvolvimiento de la justicia. En efecto, dado que las informaciones eran el material que usaban los jueces para conocer las causas y dictar sus sentencias, contar con testimonios favorables fue casi tan determinante

${ }^{80}$ Carta de Francisco Palomino al rey, Mérida, 20 de agosto de 1574. AGI, México, 99, R. 4, 7 ff.

${ }^{81}$ Cunill 2008.

${ }^{82}$ Respuesta de fray Pedro Calderón a la cuarta pregunta del interrogatorio presentado por Francisco Palomino, Mérida, 13 de marzo de 1576. AGI, Justicia, 1016, N. 10, ff. 975-976. En la alcaldía mayor de Tabasco, los naturales también pidieron al defensor Alonso Palomino que «fuese en su nombre a la Real Audiencia de México a tratar de su causa y tasación y que ellos se obligaban todos y cada uno por sí a pagar[le] muy largamente todo lo que en el discurso de su defensa gastase» (Cunill 2012b).

${ }^{83}$ Nuestras conclusiones coinciden con las presentadas por José Carlos de la Puente Luna en su trabajo sobre la inversión que realizaron los indígenas del valle de Jauja para financiar el costo de los pleitos que sostenían en la Audiencia de Lima (Puente Luna 2015). 
como estar correctamente representado en los foros de justicia. Ya se ha mencionado que Francisco Palomino puso en tela de juicio la validez de los testimonios recogidos por el gobernador Francisco de Gijón en su información de 1574, al afirmar que esta «se hizo a persuasión, inducimiento y engaño de las partes contrarias». ${ }^{84} \mathrm{El}$ defensor afirmó, asimismo, que varios de los mayas que declararon en la probanza de 1576 sufrieron represalias. Según él, el gobernador y sus secuaces "prendieron a los caciques y gobernadores indios y principales de los dichos pueblos y los trajeron a la cárcel pública de la ciudad de Mérida y los tuvieron presos muchos días y les hicieron y causaron costas». ${ }^{85}$ De hecho, los colonos tampoco dudaron en amenazar al mismo defensor, ya que, en 1576, el teniente de gobernador, el alguacil mayor y los alcaldes de Mérida fueron a su casa a medianoche, lo llevaron a la cárcel y lo pusieron en un calabazo. ${ }^{86}$

¿Cómo reaccionó la Corona española ante aquellas tensiones? Después de tan largos y complejos trámites, el Consejo de Indias dispuso, finalmente, que se diera cédula al gobernador de Yucatán "para que en las partes y lugares donde se pudiere excusar el cargarse los indios, se excuse y no se haga y donde no se pudiere excusar los carguen con carga moderada pagándoles su justo salario y de su voluntad y no de otra manera». ${ }^{87}$ Esta decisión, si bien reconocía las justas pretensiones del defensor de indios, era relativamente moderada. En realidad, se puede argüir que el Consejo de Indias no fallaba de forma tajante en los asuntos, sino que se esforzaba por mantener el equilibrio entre las fuerzas y jurisdicciones en presencia, de cuya confrontación debían surgir soluciones a nivel local. En efecto, en 1580, el monarca mandó que el defensor de indios pudiese asistir a los «ayuntamientos» o reuniones del Cabildo de la ciudad

${ }^{84}$ Alegato de Francisco Palomino, Madrid, 14 de noviembre de 1578. AGI, Justicia, 1016, N. 10, f. 892v.

${ }^{85}$ AGI, Justicia, 1016, N. 10, f. 893 r.

${ }^{86}$ Carta de Francisco Palomino al rey, Mérida, 20 de febrero de 1576. AGI, México, 101, R. 2, 2 ff.

${ }^{87}$ Sentencia del Consejo de Indias, Madrid, 13 de mayo de 1579. AGI, Justicia, 1016, N. 10 , f. $894 v$. 
de Mérida para que estuviera informado de los debates y representara los intereses indígenas en este foro de gobierno y justicia. ${ }^{88}$ Es probable que la Corona española buscara con esta medida crear un contrapeso al poder que brindaba al cabildo español el recibir traslados de todas las peticiones presentadas en la audiencia del gobernador de Yucatán. En fechas similares, el Consejo de Indias también ordenó que al menos la mitad de los cabildantes fueran pobladores y no encomenderos. ${ }^{89}$ En cambio, favoreció las pretensiones de los cabildos españoles de Yucatán frente a las intromisiones de los gobernadores, al prohibir que pudieran nombrar a más de un teniente letrado y al suspender a los corregidores. ${ }^{90}$ Se puede argüir que, de forma general, la Corona trató de mantener un equilibrio entre las fuerzas existentes mediante decisiones que atañían a aspectos jurisdiccionales.

\section{CONSIDERACIONES FINALES}

Todo indica que los oficiales de los cabildos mayas no permanecieron ajenos a los conflictos que surgieron en el Yucatán del siglo XVI entre religiosos, alcaldes ordinarios y corregidores. En efecto, para defender su propia jurisdicción dentro del complejo escenario político local, los mayas utilizaron sus conocimientos legales, fraguaron alianzas con otros sectores sociales y lucharon por estar adecuadamente representados en el

${ }^{88}$ Cédula al gobernador para que se guarden las leyes sobre sesionar de los cabildos y esté presente el protector de los indios, 21 de octubre de 1580 (Solís Robleda y Bracamonte y Sosa 2011: 381).

${ }^{89}$ Cédula al gobernador para que provea lo conveniente sobre la composición del cabildo de Mérida, 14 de octubre de 1580 (Solís Robleda y Bracamonte y Sosa 2011: 380). Esta medida recuerda la tomada por el virrey Toledo, quien ordenó en 1570 que los alcaldes ordinarios y regidores fuesen por igual encomenderos y vecinos no beneficiarios de encomienda (Levillier 1935, I: 233-239).

${ }^{90}$ Cédula al gobernador para que permita elecciones libres en Valladolid y no envíe jueces por causas leves, 5 de mayo de 1579; Cédula al gobernador que informe sobre la queja de la villa de Valladolid contra los corregidores de indios, 5 de mayo de 1579; Sobrecédula para que los gobernadores no nombren más de un teniente y cédula para que los gobernadores no nombren jueces de comisión, 31 de marzo de 1579; y Cédula al gobernador para que quite los corregidores de indios y haga justicia de agravios 11 de noviembre de 1580 (Solís Robleda y Bracamonte y Sosa 2011: 283-284, 347 y 383). 
juzgado del gobernador, en la Audiencia de México y, en última instancia, en el Consejo de Indias. Aquellos elementos constituyeron modalidades de la acción política maya en el Imperio hispánico. El presente análisis rompe, por lo tanto, con la imagen del pueblo maya concebido como territorio cerrado y aislado y aboga a favor de una concepción del mismo como un espacio abierto e integrado, marcado por un alto grado de comunicación entre los actores históricos.

Adicionalmente, el éxito en las luchas por el poder dependió, en buena medida, de la adecuada representación jurídica de los litigantes en los foros de justicia, donde se actualizaron las relaciones de poder y se articularon entre sí las distintas jurisdicciones que conformaban el complejo andamiaje político del Imperio hispánico. Así, pues, en el juzgado del gobernador de Yucatán, los defensores de indios se enfrentaron a los procuradores de los cabildos espańoles, quienes mantuvieron una intensa actividad legal para obstaculizar el cumplimiento de las disposiciones reales desfavorables a la oligarquía local y, de manera general, incidir en las políticas de la Corona espańola. En el proceso de resolución de los conflictos jurisdiccionales también resultó determinante la capacidad de los actores para entablar alianzas locales y para conseguir testimonios favorables en las informaciones que se enviaban a los tribunales como documentos probatorios. En definitiva, se puede argüir que gozar de representación jurídica en los foros de justicia del Imperio hispánico, por un lado, y consolidar el control local en los pueblos de indios, por otro, fueron dos elementos tan necesarios como complementarios para ejercer un poder efectivo en la América colonial. 


\section{BIBLIOGRAFÍA}

Assadourian, Carlos Sempat. 1990. «Fray Bartolomé de Las Casas obispo: la condición miserable de las naciones indianas y el derecho de la Iglesia (un escrito de 1545) ». Allpanchis. Vol. 12, núm. 35: 29-104.

Bayle, Constantino. 1952. Los cabildos seculares en la América española. Madrid: Sapientia.

Borah, Woodrow. 1985. El juzgado General de Indios de la Nueva España. México: Fondo de Cultura Económica.

Cartas de Indias. 1877. Madrid: Imprenta de Manuel G. Hernández.

Chuchiak, John F. 2000. «The Indian Inquisition and the Extirpation of Idolatry: The Process of Punishment in the Provisorato de Indios of the Diocese of Yucatán, 1563-1812». PhD., Tulane University.

Chuchiak, John F. 2007. «The Sins of the Fathers: Franciscan Friars, Parish Priests, and the Sexual Conquest of the Yucatec Maya, 1554-1808». Ethnohistory. Vol. 54, núm. 1: 69-158. https://doi.org/10.1215/00141801-2006-040

Clendinnen, Inga. 1986. Ambivalent Conquest: Mayas and Spaniards in Yucatán, 1517-1570. Cambridge: Cambridge University Press.

Cobo Betancourt, Juan Fernando. 2014. "Colonialism in the Periphery: Spanish Linguistic Policy in New Granada, 1574-1625». Colonial Latin American Review. Vol. 23, núm. 2: 118-142. https://doi.org/10.1080/10609164.2014.917540

Cunill, Caroline. 2008. «Negocios y justicia: Francisco Palomino, defensor de los mayas de Yucatán (1569-1586)». Temas americanistas. Núm. 20: 1-26.

Cunill, Caroline. 2012a. Los defensores de indios de Yucatán y el acceso de los mayas a la justicia real, 1550-1600. Mérida: Universidad Nacional Autónoma de México.

Cunill, Caroline. 2012b. «Los defensores de indios de la alcaldía mayor de Tabasco (siglo XVI)». Historia Mexicana. Vol. 62, núm. 2: 551-590.

Cunill, Caroline. 2015a. «La circulación del derecho indiano entre los mayas: escritura, oralidad y orden simbólico en Yucatán, siglo XVI». Anuario de Historia de América Latina-Jahrbuch für Geschichte Lateinamerikas. Vol. 52: 15-36. https:// doi.org/10.7767/jbla-2015-0103

Cunill, Caroline. 2015b. «Tenía la tierra carteada’: transferencias e hibridación en una rebelión maya de finales del siglo XVI». En Ruiz Medrano, Carlos Rubén (ed.). Los otros rebeldes novohispanos. Imaginarios, discursos y cultura politica de la subversión y la resistencia. San Luis Potosí: El Colegio de San Luis Potosí, 9-32. Elliott, John H. 1992. "A Europe of Composite Monarchies». Past and Present. Vol. 137, núm. 1: 48-71. https://doi.org/10.1093/past/137.1.48

Encinas, Diego de. 1945. Cedulario Indiano. Madrid: Cultura Hispánica, 4 vols..

Farriss, Nancy. 2012. La sociedad maya bajo el dominio colonial. La empresa colectiva de supervivencia. México: Consejo Nacional para la Cultura y las Artes.

García Bernal, Manuela Cristina. 1982. «Los franciscanos y la defensa del indio yucateco». Temas Americanistas. Núm. 1: 20-30. 
García Bernal, Manuela Cristina. 1985. "García de Palacio y sus ordenanzas para Yucatán». Temas Americanistas. Núm. 5: 1-39

García Bernal, Manuela Cristina. 2000. «Las élites capitulares indianas y sus mecanismos de poder en el siglo XVII». Anuario de Estudios Americanos. Vol. 57, núm. 1: 89-110. https://doi.org/10.3989/aea.2000.v57.i1.260

Garriga, Carlos. 2006. «Orden jurídico y poder político en el Antiguo Régimen». Istor. Vol. 16: 13-44.

González Cicero, Stella María. 1978. Perspectiva religiosa en Yucatán, 1517-1571. México,: El Colegio de México.

Gorissen, Matthias. 2007. «The Enemy Without, the Enemy Within: Fear, Conspiracy, and Rebellion in Early Colonial Yucatan». Anuario de Historia de América Latina - Jahrbuch für Geschichte Lateinamerikas. Núm. 44: 67-91. https://doi. org/10.7767/jbla.2007.44.1.67

Grossi, Paolo. 1996. El orden jurídico medieval. Madrid: Marcial Pons.

Güémez Pineda, Arturo. 2005. «El poder de los cabildos mayas y la venta de propiedades privadas a través del Tribunal de Indios, Yucatán (1750-1821)». Historia Mexicana. Vol. 54, núm. 3: 697-760.

Guibovich Pérez, Pedro. 2011. «Visitas eclesiásticas y extirpación de la idolatría en la diócesis de Lima en la segunda mitad del siglo XVII». En Zaballa Beascoechea, Ana de (ed.). Los indios, el Derecho canónico y la justicia eclesiástica en la América virreinal. Madrid: Iberoamericana, 177-202.

Hanks, William F. 2010. Converting Words. Maya in the Age of the Cross. Berkeley: University of California Press. https://doi.org/10.1525/ california/9780520257702.001.0001

Herzog, Tamar. 2013. «Colonial Law and 'Native Customs': Indigenous Land Rights in Colonial Spanish America». The Americas. Vol. 69, núm. 3: 303-321. https:// doi.org/10.1017/s0003161500002303

Las Casas, Bartolomé de. 1995. Cartas y memoriales. Madrid: Alianza Editorial.

Lentz, Mark W. 2012. "Batabs of the Barrio: Urban Maya Rulers, Mérida, Yucatan, 1670-1806». En Velasco Murillo, Dana, Mark Lentz y Margarita R. Ochoa (eds.). City Indians in Spain's American Empire. Urban Indigenous Society in Colonial Mesoamerica and Andean South America, 1530-1810. Brighton: Sussex Academic Press, 172-198.

Levillier, Roberto. 1935. Don Francisco de Toledo, supremo organizador del Perú. Su vida y su obra. Madrid: Espasa- Calpe, 2 vols.

Okoshi Harada, Tsubasa. 2006. «Otra lectura de la 'Memoria de la distribución de los montes (1557)' de los Papeles de los Xiu de Yaxá, Yucatán». En Barrera Rubio, Alfredo y Ruth Gubler (eds.). Los mayas de ayer y hoy. Mérida: Instituto Nacional de Antropología e Historia, vol. II, 778-791.

Prodi, Paolo. 2000. Una storia della giustizia. Dal pluralismo dei fori al moderno dualismo tra coscienza e diritto. Bologna: Societa Editrice il Mulino. 
Puente Luna, José Carlos de la. 2015. «That Which Belongs to All: Khipus, Community, and Indigenous Legal Activism in the Early Colonial Andes». The Americas. Vol. 72, núm. 1: 19-59. https://doi.org/10.1017/tam.2015.28

Puente Luna, José Carlos de la. 2016. «En lengua de indios y en lengua castellana: cabildos de naturales y escritura alfabética en el Perú colonial». En Izquierdo y de la Cueva, Ana Luisa (coord.). Visiones del pasado. Reflexiones para escribir la historia del pasado indígena en América Latina. México, D. F.: Universidad Nacional Autónoma de México [en prensa].

Puga, Vasco de. 1945. Provisiones, cédulas e instrucciones para el gobierno de la Nueva España. Madrid: Cultura Hispánica, 3 vols.

Quezada, Sergio. 2014. Maya Lords and Lordship: The Formation of Colonial Society, 1350-1600. Norman: University of Oklahoma Press.

Quezada, Sergio y Anabel Torres Trujillo. 2010. Tres nobles mayas yucatecos. Mérida: Instituto de Cultura de Yucatán.

Quezada, Sergio y Tsubasa Okoshi Harada. 2001. Los papeles de los Xiu de Yaxá, Yucatán. México, D. F.: Universidad Nacional Autónoma de México.

Quijano, Francisco. 2012. "Alonso de la Veracruz: Natural Law, Dominion and Political Legitimacy in Native American Governance». En Paul, Joanne (ed.). Governing Diversity: Democracy, Diversity and Human Nature. Cambridge: Cambridge Scholars Publishing, 89-106.

Quijano, Francisco. 2016. «Los argumentos del ayuntamiento de México para destituir al corregidor en el siglo XVI. El pensamiento político novohispano visto desde una institución local». Estudios de Historia Novohispana [en prensa]. Raimúndez Ares, Zoraida. 2016. Las cartas de los caciques de Yucatán a Felipe II, de 1567. Trabajo de fin de Máster. Universidad Complutense de Madrid, Departamento de Historia de América.

Restall, Matthew. 1995. «He Wished it in Vain: Subordination and Resistance among Maya Women in Post-Conquest Yucatan». Ethnohistory. Vol. 42: 577-594. https://doi.org/10.2307/483144

Restall, Matthew. 1997. The Maya World. Yucatec Culture and Society, 1550-1850. Stanford: Stanford University Press.

Rocher Sala, Adriana. 2004. «Entre el cordón de San Francisco y la Corona de San Pedro. La administración parroquial en Yucatán». Estudios de Cultura Maya. Vol. 25: 149-168.

Rubio Mañé, José Ignacio. 1942. Archivo de la historia de Yucatán, Campeche y Tabasco. México, D. F.: Aldina, Robredo y Rosell, 3 vols.

Ruiz Medrano, Ethelia. 2002. «Poder e Iglesia en Nueva España. La disputa del diezmo». En Román Gutiérrez, José, Enrique Martínez Ruiz y Jaime González Rodríguez (coords.). Felipe II y el oficio de rey: la fragua de un imperio. Madrid: Sociedad Estatal para la Conmemoración de los Centenarios de Felipe II y Carlos V, 835-867. 
Russell, Conrad y José Andrés-Gallego (dirs.). 1996. Las Monarquías del Antiguo Régimen, ¿monarquias compuestas? Madrid: Editorial Complutense.

Sánchez Bella, Ismael. 1991. Derecho Indiano. Estudios. Visitas generales en la América española (siglos XVI-XVII). Pamplona: Ediciones Universidad de Navarra.

Scholes, France V. y Eleanor Adams (eds.). 1938. Don Diego Quijada, alcalde mayor de Yucatán, 1561-1565. México, D. F.: Antigua Librería Robredo, 2 vols.

Sigal, Pete. 2000. From Moon Goddesses to Virgins: The Colonization of Yucatecan Maya Sexual Desire. Austin: University of Texas Press.

Solano, Francisco de. 1991. Documentos sobre la politica lingüística en Hispanoamérica, 1492-1800. Madrid: Consejo Superior de Investigaciones Científicas.

Solís Robleda, Gabriela. 2013. Entre litigar justicia y procurar leyes. La defensoría de indios en el Yucatán colonial. Mérida: Centro de Investigaciones y Estudios Superiores en Antropología Social.

Solís Robleda, Gabriela y Pedro Bracamonte y Sosa (eds.). 2011. Cedulario de la dominación española en Yucatán, siglo XVI. México: Centro de Investigaciones y Estudios Superiores en Antropología Social.

Tau Anzoátegui, Víctor. 1980. «La ley 'se obedece pero no se cumple': en torno a la suplicación de las leyes en el Derecho Indiano». En V Congreso del Instituto Internacional de Historia del Derecho Indiano. Quito: Ediciones Corporación de Estudios y Publicaciones, vol. II, pp. 55-112.

Thompson, Philip C. 1999. Tekanto. A Maya Town in Colonial Yucatán. Tulane University: Middle American Research Institute.

Traslosheros, Jorge E. 2002. «El tribunal eclesiástico y los indios en el arzobispado de México hasta 1640». Historia Mexicana. Vol. 60, núm. 3: 485-516.

Traslosheros, Jorge E. y Ana de Zaballa Beascoechea (coords.). 2010. Los indios ante los foros de justicia religiosa en la Hispanoamérica virreinal. México: Universidad Nacional Autónoma de México.

Zaballa Beascoechea, Ana de. 2011a. «Reflexiones en torno a la recepción del Derecho Eclesiástico por los indígenas de Nueva España». En Zaballa Beascoechea, Ana de (ed.). Los indios, el Derecho canónico y la justicia eclesiástica en la América virreinal. Madrid: Iberoamericana, 45-68.

Zaballa Beascoechea, Ana de. (ed.). 2011 b. Los indios, el Derecho canónico y la justicia eclesiástica en la América virreinal. Madrid: Iberoamericana.

Fecha de recepción: 16/VI/2016

Fecha de aceptación: 19/VII/2016 